\title{
"Humanism" and "Humanness": Dissolution and Reconstruction of Human Subjectivity in the Horizon of Technological Alienation
}

\author{
Qinglong Zhou ${ }^{1}$ \\ ${ }^{1}$ School of Marxism, University of Science and Technology of Suzhou, Suzhou, China \\ Correspondence: Qinglong Zhou, School of Marxism, University of Science and Technology of Suzhou, Suzhou, \\ China. E-mail: 2038496720@qq.com
}

Received: July 18, 2021

Accepted: August 30, $2021 \quad$ Online Published: August 30, 2021

doi:10.5539/jpl.v14n3p149

URL: https://doi.org/10.5539/jpl.v14n3p149

Fund Project: Philosophy and Social Science Research Project in Jiangsu Province, "Research on the Issues and Countermeasures of College Students' Socialist Core Value Identity Education" (2017SJBFDY643)

\begin{abstract}
The inquiry into the nature of modern science and technology is an in-depth discussion of the relationship between science and technology and human lifestyles, and the alienation of science and technology is a problem area that occupies an important position in this discussion. From a philosophical point of view, the humanistic and moral consideration of the alienation of science and technology, the comprehensive study and overview of the dialectical relationship between man and science and technology, are helpful to clarify the constructive relationship between the essence of science and technology and the true subjectivity of man. The essence of science and technology lies in the essence of human beings, and the root of the alienation of science and technology lies in the alienation of human nature. Therefore, from the perspective of "being human", through the liberation of modern science and technology, we can achieve the weakening of the alienation of science and technology, in order to realize the reconstruction of human subjectivity, and provide for the weakening of the shackles brought by the development of modern science and technology and the realization of free development of human beings. The theoretical perspective of philosophy.
\end{abstract}

Keywords: alienation of science and technology, human subjectivity, humanness

\section{Introduction}

With the rapid development of modern science and technology, the phenomenon of technological alienation has become more and more common in modern times. The technology created by man should be aimed at man, but the subjectivity of man is more and more suppressed. Instead, man has become more of an instrumental means. The separation of tools and rationality, and the separation of humanities and technology are the shackles of the rapid development of science and technology. How to avoid the negative effects brought about by the alienation of science and technology, make science and technology develop in the direction of "being human", and further realize the coordination between scientific and technological progress and human development, has become a more concerned field of vision in academic circles. Researching and solving the problem of the elimination of human subjectivity from the perspective of technological alienation, reconstructing and promoting human-led value rationality, has become a top priority in contemporary society.

\section{Technology: An Instrumental Extension of the Essential Power of Human}

Science and technology are tools and media for the relationship between people and objects, and are the results of people's inventions and creations according to the needs of their own practical activities. In this process, the free and conscious existence of human beings is the main body of science and technology. At the same time, science and technology are the instrumental extension of the essential power of human being created by humans, and the dialectical relationship between human and science and technology is complementary to each other.

\subsection{People Are the Main Body of Science and Technology}

The human issue is the core issue of Marxist philosophy, and realistic humans and their historical development are the fulcrum of the Marxist philosophical system. In Marxist philosophy, "human" is neither a "unmanned reason" 
in the Hegelian sense, nor a "separate body" in the sense of Feuerbach's humanism, but a "reality" engaged in actual activities. "The individual", this "real person" shows us the existence of subjectivity, history and transcendence. Man is the subject, as the subject of practice, and at the same time the subject in the relationship of practice.

First of all, science and technology are the product of practice, and humans exist as the subject of practice, so humans are the subject of science and technology. Secondly, science and technology, as the medium and means by which mankind understands and transforms the world, "exists for me". In the relationship between man and science and technology, man occupies a dominant position. Thirdly, in the process of human beings as the subject and other things, the performance of science and technology as human's essential power is subordinate to humans, rather than external to humans. At the same time, the application of science and technology is not unlimited and aimless, but is controlled and guided by humans. In its essence, science and technology are man's purposeful activities, which are activities that the subject sees from the object, and science and technology can never exist independently of the human subject. Therefore, as a kind of initiative and free conscious existence, man is the subject of science and technology.

\subsection{Science and Technology Are the Essential Power of Human Beings}

Science and technology are produced in the process of object activities, especially material production activities, between man and the objective world. It not only carries the aspirations of human survival and development, but also symbolizes the exertion and exaltation of human subjectivity. As Marx said, Science and technology is "an opened book about the essential power of man"1 In this judgment, we can clearly realize that technology is human technology, and technology is human's essential power.

First of all, from the perspective of the root cause, science and technology are the carriers of the externalization of the essential power of man, and the "open display of the essential power of man" ${ }^{2}$ In the "Manuscript of Economics and Philosophy in 1844", Marx believed that as a conscious being, "kind" is his own essence. As a kind of "kind being", human beings need to create the object world through practice and then transform the inorganic world. In this kind of creative activity, science and technology are not a useful tool external to humans, but the use of human essential power to act on the world of objects. In a certain sense, science and technology are extensions of the human body. Secondly, from a functional perspective, science and technology are tools and media for the relationship between people and objects, and are the results of people's inventions and creations according to the needs of their own practical activities. In the process of understanding and transforming the material world, people's survival needs to urgently require them to exert their subjective initiative to create tools that are both external and internal as the extension of human's essential power and have a direct relationship with nature.

\subsection{Complementation of People and Technology}

People are the main body of science and technology, and science and technology are an important driving force for human progress. The two complement and promote each other in their interaction.

First of all, the development of science and technology promotes the progress of human civilization, and science and technology is the highest revolutionary force that promotes the advancement of human history. Science and technology, as a means and tool for mankind to understand and transform the world, its development will inevitably bring about the innovation of productivity. At the same time, the development of science and technology has promoted the transformation of production relations. The basic principle of historical materialism shows that productivity determines production relations, and the development of science and technology promotes the progress of productivity, and therefore will inevitably promote the transformation of production relations. In addition, the development of science and technology has also promoted social and cultural changes, which are not only manifested in cultural forms such as language and writing, but also in cultural connotations and carriers.

Secondly, the progress of human society will inevitably lead to the redevelopment of science and technology. Science and technology stand on the shoulders of human society and continue to move towards a higher direction. While science and technology promote the progress of human society, mankind will face many new situations. In the face of this situation, humanity's desire for knowledge and survival needs will once again issue an urgent need for science and technology, and objectively require science and technology to be unknown to mankind. Exploring new fields and unfamiliar spaces will inevitably lead to another advancement in science and technology. Human society and science and technology always present a state of continuous advancement, continuous transcendence

\footnotetext{
${ }^{1}$ Marx, Engels. Collected Works of Marx and Engels [M]: Volume 1. Beijing: People's Publishing House, 2009:192.

${ }^{2}$ Marx, Engels. Collected Works of Marx and Engels [M]: Volume 1. Beijing: People's Publishing House, 2009:193.
} 
and continuous development in this interaction.

In short, human and technology have a complementary relationship. If science and technology leave human beings, they will lose the premise and possibility of existence, and if human beings leave science and technology, they will lose the motivation and foundation for development and progress.

\section{The Alienation of Science and Technology: The Dissolution of Human Subjectivity}

Science and technology are the results of human objectification activities, and its powerful driving force for social development is unquestionable. "All our discoveries and progress seem to result in material forces with rational life, while human life turns into dull material forces." ${ }^{13}$ The development of science and technology is the same as anything. In the process of "Humanism" science and technology "Humanness", people inevitably produce an alien force that is not conducive to human survival and development, that is, technological alienation.

\subsection{Technology's Alienation of People's Lifestyle}

Technology has created huge material wealth for mankind. While enjoying the great convenience of this material, mankind also subtly develops a strong dependence on material. If we lose the products created by technology for us in our lives, there are many things that people can't do. Technology has degraded human activities, and humans have to rely on certain technological products to achieve their own goals. Nowadays, there are "mobile phone dependence", "network dependence", "express dependence" and so on. People will become irritable and restless when they leave their mobile phones; when people face new problems, more of the first reaction is to search on the Internet; Check the logistics information of the goods you buy on the Internet over and over again. It is not to deny the great contribution of high-tech products such as mobile phones and the Internet to mankind, but to say that human beings' over-reliance on technology products will not only affect normal life, but also degrade their own creativity, communication skills, and other abilities of human subjectivity. This is the state of human dependence on science and technology and the enslavement of science and technology to people caused by the unconscious dependence on science and technology in the process of using science and technology.

\subsection{The Alienation of Human Spirit and Culture by Technology}

Technology helps people confirm the meaning of this world, but it also makes value nihilism prevail. Science and technology has made people's cultural activities more and more diversified. At the same time, cultural products have become more and more commercial after being packaged by science and technology. Modern people's pursuit of material makes cultural activities driven by material benefits, and the organizers of cultural activities pay more attention to the issue of capital income. In today's environment where people are overly pursuing interests, cultural products just blindly pursue commercial value without considering the spiritual connotation of cultural products. Emerging video interactive platforms such as Douyin and Kuaishou sometimes blindly cater to the low-level preferences of some consumers regardless of the bottom line of the culture, which will inevitably lead to cultural products becoming more and more nasty and vulgar.

\subsection{Technology's Alienation of Human's Own Physiology and Psychology}

\subsubsection{Genetically Modified Food}

The safety of genetically modified food is one of the most controversial topics today. Transgenic technology brings many benefits in the actual application process. For example, transgenic technology can increase the yield and quality of crops, increase the ability of crops to resist pests, and extend the maturity speed for storage. However, genetically modified foods also bring certain safety hazards. Related experiments conducted by some researchers have shown that the mortality rate of chickens that eat genetically modified feed is nearly two times higher than that of naturally grown chickens. Pigs that eat genetically modified corn There will be false pregnancy and even infertility, etc. These experimental results can't help but cause people to worry about the safety of genetically modified foods.

\subsubsection{Medicines}

The use of medicine has enabled thousands of people on the verge of life and death to be treated, but it will also bring a series of adverse effects to the human body. For example, analgesic drugs commonly used in medical procedures, such as fenbid, aspirin, etc., are extremely irritating to the human stomach, making patients taking such drugs more likely to have gastric bleeding. Increase; for example, pethidine, morphine and other powerful analgesics, patients will have a strong addiction and dependence on such drugs. The invention of antibiotics can be said to be one of the most significant achievements in the history of microbiology. Antibiotics can kill bacteria

\footnotetext{
${ }^{3}$ Marx, Engels. Collected Works of Marx and Engels [M]: Volume 1. Beijing: People's Publishing House, 1972:517.
} 
and treat infectious diseases, but they also have many undesirable effects during use. For example, taking antibiotics for a long time will reduce the sensitivity of the bacteria in the body to antibiotics, and as a result, the antibiotics will not work on the bacteria in the human body; It will make the body's ability to produce immune substances weaker and weaker, resulting in a decline in the body's resistance and more susceptibility to bacterial infections. Although hormone drugs have a faster and better therapeutic effect on related diseases, the abuse of such drugs can also bring some adverse effects.

In addition to the adverse effects on human physiology, the alienation of science and technology also has a destructive effect on human psychology in a certain sense. Modern science and technology only pay attention to "materials" and ignore "humanities". Although the modern industrial society formed in this state will bring great freedom and convenience to people, it will also bring all kinds of compulsory conditions to mankind at the same time. This creates a society with only material life but no spiritual life. In such a society, people become utilitarian, numb, and numb "one-dimensional people" who only pursue material comforts, lack the ability to judge their surroundings. ". Such "one-dimensional people" are driven by material interests, and their spiritual life is left behind, leading to the loss of the human spiritual world. Such people have also been deprived of their right to freedom and gradually lost their status as the main body of scientific and technological activities.

\section{Sublation of Technological Alienation: Reconstruction of Human Subjectivity}

The negative social function of science and technology mentioned in the "original sin" theory of science and technology cannot be attributed to science and technology itself. This is contrary to Marx's view that science and technology are a great revolutionary force. The essence of science and technology alienation is the nature of human beings of alienation. Facing the phenomenon of technological alienation, we should base on the essence of technological alienation, that is, the nature of human beings, and weaken and sublate the alienation of science and technology.

\subsection{The All-Round Development of Human Beings Provides the Subjective Conditions for the Development of Science and Technology}

The basic content of Marx's all-round development of human beings includes four aspects: the all-round development of human needs, the full development of human abilities, the all-round enrichment of human social relations, and the full development of human personality. A fully developed person is the perfect state of a person in a communist society. Technology is produced by people's desires and needs, is subject to people's creative ability, and is updated by people's social interactions. The development of science and technology is inseparable from the development of the people who created it. In the final analysis, as a product of human labor, science and technology rely on human inventions and creations. Only when the overall development of people is realized can science and technology be iteratively updated on this basis and become more complete. The function. As Marx said, independent talents have the ability to be independent, and only when they have the ability to be independent can they be free. If human beings can continuously work towards these aspects of human development, then some of the shortcomings in the development of science and technology, such as focusing only on the economic value and utilitarian value of science and technology, and ignoring the spiritual value and humanistic value of science and technology; only focusing on satisfying people The material needs of people, while ignoring other needs of people, etc., can be overcome to a certain extent.

\subsection{Science and Technology Provide Preconditions for Human Development}

Science and technology, an important tool for liberating and developing productive forces, can provide preconditions for human development. "Science and technology are the results of human object activities, and the theoretical and practical crystallization of human object relationships, especially the relationship between man and nature." 4 After the birth of science and technology, the direct function is to help human beings play a role in their production activities. The influence it brings will strengthen the communication between people and further broaden the relationship between people and things. The social circle of the society in turn deepens the relationship between people and the objective beings they transform, including the relationship between people and natural beings, as well as the social contacts between people. On this basis, the instrumental rationality and value rationality of human beings as subjectivity have been continuously promoted and manifested in the rich material life and outstanding spiritual quality. In modern times, science and technology and its rapid development have occupied all aspects of people's daily lives. Technology and people have become inseparable. In a certain sense, people have become scientific and technological people. In other words, technology has turned into human blood and limbs. Exist, it is difficult for human beings to escape from the normal life of science and technology. At the

${ }^{4}$ Xia Zhentao. What is a person [M]. Beijing: The Commercial Press, 2000: 342-343. 
same time, it is precisely this advanced science and technology that has opened up the time for active existence and the space for high-level development for modern people.

On the one hand, the development of modern science and technology has created an unprecedented high degree of possibility for the creation of human subjective initiative and the all-round development of human beings. On the other hand, we should also see that the existence of possibility does not have the realization of reality, and that there are many social conditions that straddle the possibility and reality. Only when science and technology are completely entrusted to and under the absolute rule of man, can the development of science and technology become a stable force to promote the progress of human society. If not, man will be enslaved by dehumanized technology, and technology will Cause unpredictable harmful consequences and disasters to workers.

In short, in the process of realizing the modernization of science and technology, "people are the designers, manufacturers, users, and controllers of man-made objects. Human power is the unity of one's own power and the power of things. ${ }^{5}$ The interaction between human development and technological development is a necessary condition for weakening the alienation of science and technology, and only through passing can we sublate, make science and technology develop in the direction of "being human", and realize the active unity of scientific and technological progress and human development.

\section{References}

Lin, D. H. (1999). Dehumanization of Criticism - A Modern Technological Mechanical Theory. Studies in Dialectics of Nature, (3), 27.

Marx, \& Engels. (2009). Collected Works of Marx and Engels (Vol. 1, pp. 192, 197). Beijing: People's Publishing House.

Nicholas, N. (1995). Being Digital (pp. 22). New York: Kno-pf.

Samuel, H., \& Lawrence, H. (2010). The Importance of Culture-How Values Affect Human Progress (pp. 121). Translator: Cheng Kexiong. Beijing: Xinhua Publishing House.

Xia, Z. T. (2000). What is a person (pp. 342-343). Beijing: The Commercial Press.

\section{Copyrights}

Copyright for this article is retained by the author(s), with first publication rights granted to the journal.

This is an open-access article distributed under the terms and conditions of the Creative Commons Attribution license (http://creativecommons.org/licenses/by/4.0/).

\footnotetext{
${ }^{5}$ Lin Dehong. Dehumanization of Criticism - A Modern Technological Mechanical Theory [J]. Studies in Dialectics of Nature, 1999 (3): 27.
} 